\title{
Short-term low-severity spring grassland fire impacts on soil extractable elements and soil ratios in Lithuania
}

\author{
Paulo Pereira ${ }^{\mathrm{a}, *}$, Artemi Cerda $^{\mathrm{b}}$, Deborah Martin ${ }^{\mathrm{c}}$, Xavier Úbeda ${ }^{\mathrm{d}}$, Daniel Depellegrin ${ }^{\mathrm{a}}$, Agata Novara ${ }^{\mathrm{e}}$, \\ Juan F. Martínez-Murillo ${ }^{\mathrm{f}}$, Eric C. Brevik ${ }^{\mathrm{g}}$, Oleksandr Menshov ${ }^{\mathrm{h}}$, Jesus Rodrigo Comino ${ }^{\mathrm{i}, \mathrm{j}}$, Jessica Miesel ${ }^{\mathrm{k}}$ \\ a Environmental Management Center, Mykolas Romeris University, Ateities g. 20, LT-08303 Vilnius, Lithuania \\ b SEDER Soil Erosion and Degradation Research Group, Department of Geography, University of Valencia, Valencia, Spain \\ c USGS, 3215 Marine Street, Boulder, CO, USA

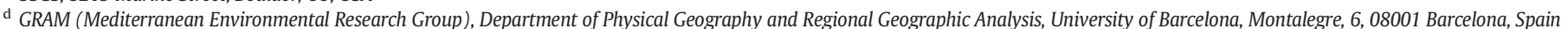 \\ e Dipartimento di Scienze agrarie e forestali, University of Palermo, 90128 Palermo, Italy \\ ${ }^{\mathrm{f}}$ Department of Geography, University of Málaga, Andalucía Tech. Campus de Teatinos, 29071 Málaga, Spain \\ g Department of Natural Sciences, Dickinson State University, Dickinson, ND 58601, USA \\ h Taras Shevchenko National University of Kyiv, Institute of Geology, 90 Vasylkivska str., Kyiv, Ukraine \\ i Instituto de Geomorfología y Suelos, University of Málaga, Edificio Ada Byron, Ampliación del Campus de Teatinos, 29071 Málaga, Spain \\ j Department of Physical Geography, Trier University, D-54286 Trier, Germany \\ ${ }^{\mathrm{k}}$ Department of Forestry, Michigan State University, East Lansing, MI 48825, USA
}

\section{H I G H L I G H T S}

- Short-term spring low severity grassland fire impacts on soil properties were analysed.

- Fire impacts were mainly observed in the first two months.

- Fire increased soil EC of $\mathrm{Ca}, \mathrm{Mg}$ and $\mathrm{K}$, did not change $\mathrm{Na}$, Fe and $\mathrm{Zn}$ and reduced $\mathrm{Al}$ and $\mathrm{Mn}$.

- Fire did not affect SPAR, decreased $\mathrm{Ca}: \mathrm{Mg}$ ratio, and increased $\mathrm{Ca}: \mathrm{Al}$ ratio immediately after the fire.

- This grassland ecosystem is resilient to low severity spring fires.

\section{G R A P H I C A A B S T R A C T}

Fire impacts on soil extractable elements and ratios between burned and unburned areas for different periods after fire occurrence

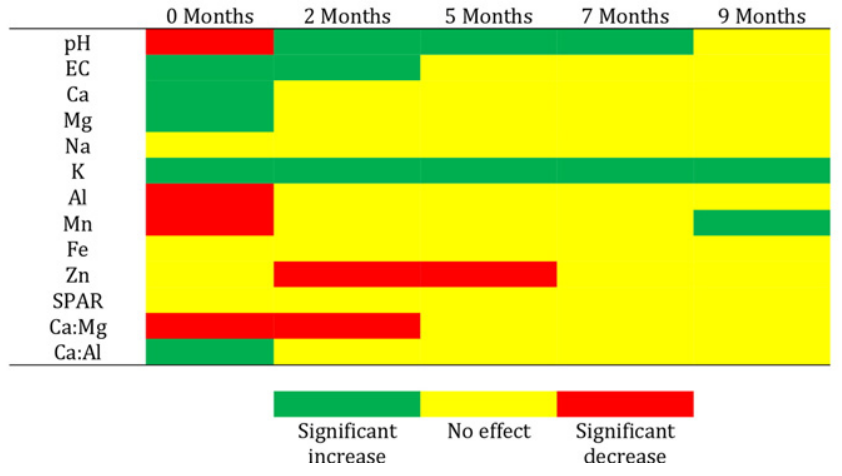

\section{A B S T R A C T}

Spring grassland fires are common in boreal areas as a consequence of slash and burn agriculture used to remove dry grass to increase soil nutrient properties and crop production. However, few works have investigated fire impacts on these grassland ecosystems, especially in the immediate period after the fire. The objective of this work was to study the short-term impacts of a spring grassland fire in Lithuania. Four days after the fire we established a $400 \mathrm{~m}^{2}$ sampling grid within the burned area and in an adjacent unburned area with the same topographical, hydrological and pedological characteristics. We collected topsoil samples immediately after the fire ( 0 months), 2, 5, 7 and 9 months after the fire. We analysed soil pH, electrical conductivity (EC), major nutrients including

Editor: D. Barcelo

* Corresponding author.

E-mail addresses: pereiraub@gmail.com (P. Pereira), artemio.Cerda@uv.es (A. Cerda), damartin@usgs.gov (D. Martin), xubeda@gmail.com (X. Úbeda), danny_green@hotmail.com (D. Depellegrin), agata.novara@unipa.it (A. Novara),jfmmurillo@uma.es (J.F. Martínez-Murillo), eric.brevik@dickinsonstate.edu (E.C. Brevik), menshov.o@ukr.net (O. Menshov), rodrigo-comino@uma.es (J.R. Comino), mieselje@msu.edu (J. Miesel). 
Keywords:

Boreal grasslands

Slash and burn

Dry grass

Soil nutrients calcium (Ca), magnesium (Mg), sodium (Na), and potassium (K), and the minor elements aluminium (Al), manganese ( $\mathrm{Mn}$ ), iron ( $\mathrm{Fe}$ ) and zinc ( $\mathrm{Zn})$. We also calculated the soil Na and K adsorption ratio (SPAR), Ca:Mg and $\mathrm{Ca}$ :Al. The results showed that this low-severity grassland fire significantly decreased soil pH, Al, and Mn but increased EC, Ca, Mg, and K,. There was no effect on Na, Fe, and Zn. There was a decrease of EC, Ca, Mg, and Na from 0 months after the fire until 7 months after the fire, with an increase during the last sampling period. Fire did not significantly affect SPAR. Ca:Mg decreased significantly immediately after the fire, but not to critical levels. Ca:Al increased after the fire, reducing the potential effects of Al on plants. Overall, fire impacts were mainly limited to the immediate period after the fire.

\section{Introduction}

Spring grassland fires are common in boreal ecosystems after winter to remove dead grasses as a result of slash and burn agricultural practices. This activity is carried out on an annual basis. In the early spring, grassland areas are covered by highly flammable dry grass that burns easily. The fires that occur during this period have insignificant effects on soil organic matter concentration, and can be positive for wildlife habitat and human activities such as the creation of pastures for grazing and open areas for cattle (Granstrom, 2001; Granstrom and Niklasson, 2008; Pereira et al., 2013b, 2013c). The vegetation normally recuperates rapidly after grassland fires (Pereira et al., 2013a, 2013b; Valko et al., 2016). Despite the frequency of grassland fires in European boreal grasslands, few studies about the impact of these fires on soil properties have been carried out (Pereira et al., 2014a; Végvári et al., 2016).

Fire is considered a soil forming factor (Certini, 2014) and its impacts on soil properties depend on the type of soil and vegetation affected, fire severity, type of ash produced, topography, aspect, and meteorological characteristics during and after the fire (Bodí et al., 2014; Brook and Wittenberg, 2016; Campos et al., 2016; Mataix-Solera et al., 2009; Unzue-Belmonte et al., 2016). One of the most widely reported impacts of heating and fire on soils is pH change (Blank et al., 2003; Marcos et al., 2007), which it is attributed to the denaturation of soil organic acids (Certini, 2005), the formation of oxides (Giovannini et al., 1988), and incorporation of ash into the soil profile (Pereira et al., 2014b; Raison and McGarity, 1980). Low-severity fires or prescribed fires do not have any impact (Marcos et al., 2009) or increase soil pH (Úbeda et al., 2005) in the period immediately after a fire. Moderate or severe wildfires typically increase soil pH for a short to medium time after a fire (Murphy et al., 2006; Martínez-Murillo et al., 2016); however, this effect depends on the type of soil affected. For example, Badia et al. (2014) observed no difference in soil pH between burned and unburned areas after a moderate to high severity wildfire in calcareous soils. The increase in soil pH after a fire can change soil nutrient availability (Certini, 2005; Wang et al., 2016), with implications for plant recuperation after the fire. Similarly, organic matter mineralization and ash incorporation into burned soils can increase electrical conductivity (EC) due to the greater solubility of major cations such as calcium (Ca), magnesium $(\mathrm{Mg})$, sodium $(\mathrm{Na})$ or potassium $(\mathrm{K})$ caused by increased $\mathrm{pH}$. In contrast, the solubility of minor elements such as aluminium (Al), manganese (Mn), iron (Fe) or zinc (Zn) may be decreased (Badia et al., 2014; Inbar et al., 2014; Ponder et al., 2009).

Despite abundant research about fire impacts on soil chemistry (Gomez-Rey et al., 2013; Shakesby et al., 2015; Tomaz et al., 2014; among others), few publications have included analyses of the ratios between soil chemical elements (Blank et al., 2003; Inbar et al., 2014) beyond the frequently reported carbon to nitrogen ratio. Soil ratios can give us information about changes in soil properties (e.g., sealing of soil pores, water infiltration, erosion potential, acidity) or risk to plant nutrition and growth (Cronan and Grigal, 1995; Narhi et al., 2013), which are important to assess in burned areas. For example, sodium adsorption ratio (SAR) is used to identify the impact of salts on clay dispersion. However, previous reports showed that ash and soil solutions can be rich in K after fire (Gimeno-Garcia et al., 2000; Pereira et al., 2012, 2014b), which can also have important influences on clay dispersion and soil structure. Sodium ( $\mathrm{Na}$ ) and $\mathrm{K}$ are recognized as nutrients with a high capacity to disperse soil clays (Levy and Torrento, 1995; Pils et al., 2007). Thus, a new cation ratio was proposed by Sarah (2004) called sodium and potassium adsorption ratio (SPAR), which calculates the ratio between monovalent ( $\mathrm{Na}$ and $\mathrm{K}$ ) and bivalent ( $\mathrm{Ca}$ and $\mathrm{Mg}$ ) cations. The soil Ca:Mg ratio is an indirect indicator of soil structure. Calcium ions have a higher flocculation capacity than $\mathrm{Mg}$ ions. This is attributed to the larger Mg ion hydrated radius. Solutions with higher $\mathrm{Mg}$ than Ca can have negative implications on soil structure, infiltration, and hydraulic conductivity (Bame et al., 2013; Yilmaz et al., 2005). The ratio between soil $\mathrm{Ca}$ and $\mathrm{Mg}$ also affects the behaviour of other nutrients such as phosphorous (Manimel Wadu et al., 2013), nitrogen (Favaretto et al., 2012), and copper (Lombini et al., 2003), as well as plant biomass and nutrient accumulation in tissues (Kopsell et al., 2013; Drzewiecka et al., 2014). The soil Ca:Al ratio is an indicator of ecosystem stress as a result of acid deposition and soil infertility. For example, Al toxicity may inhibit plant nutrient uptake (Cronan and Grigal, 1995). Previous research has shown that in low-severity fires, extractable $\mathrm{Al}$ can increase in ash slurries relative to the unburned sample (Pereira et al., 2011a) with potential impacts on soil acidity. Despite the importance of the analysis of these ratios for understanding fire effects on soil status and the capacity of vegetation to recover after fire, few publications to our knowledge have investigated their temporal evolution in fire-affected areas. A recent work carried out by Francos et al. (2016) studied the impacts of an extreme rainfall period on SPAR, but did not compare it with an unburned area. The goal of this work was to study the impacts of a low severity grassland fire on soil extractable elements and ratios in the first 9 months after the fire.

\section{Materials and methods}

\subsection{Study area, sample design and laboratory analysis}

The fire occurred on 15 April 2011 and affected an area of approximately 22.5 ha. The burned area was located near Vilnius, Lithuania at $54^{\circ} 42^{\prime} \mathrm{N}, 25^{\circ} 08^{\prime} \mathrm{E}$ with an elevation of $158 \mathrm{~m}$ a.s.l. (above sea level). The fire was anthropogenic, as a consequence of burning wood residues and grass. The soil is classified as an Albeluvisol (WRB, 2014) with a silt loam texture. The vegetation was mainly composed of fall dandelion (Leontodon autumnalis L.) and sweet vernal grass (Anthoxanthum odoratum L.). Mean annual temperature is $8.8^{\circ} \mathrm{C}$ and total annual rainfall is $735 \mathrm{~mm}$ (Pereira et al., 2014a). Four days after the fire we selected flat burned and unburned areas with the same topographical characteristics and established a plot of $400 \mathrm{~m}^{2}(20 \times 20 \mathrm{~m}$, with a grid with $5 \mathrm{~m}$ spacing between sampling points) in each of the two areas. We collected 25 individual samples of mineral soil ( $0-5 \mathrm{~cm}$ depth, single sample) on each of five different sampling dates at the same gridpoints $0,2,5,7$ and 9 months after the fire. We sampled at $5 \mathrm{~cm}$ depth in order to identify the direct and indirect impacts of fire on the first $5 \mathrm{~cm}$ of the soil, as used in previous works (Francos et al., 2016). The ash layer was removed prior to sampling. Two months after the fire the ash layer was 
very thin and sporadic and 5 months after the fire there was no evidence of ash on the soil surface. Soil samples were stored in plastic bags and taken to the laboratory where they were dried at room temperature for $24 \mathrm{~h}$ before sieving with a $2 \mathrm{~mm}$ mesh screen. A subsample of the sieved soils was taken to analyse soil $\mathrm{pH}, \mathrm{EC}$, and water-extractable ions ( $\mathrm{Ca}, \mathrm{Mg}, \mathrm{Na}, \mathrm{K}, \mathrm{Al}, \mathrm{Mn}, \mathrm{Fe}$, and $\mathrm{Zn}$ ) with a solution of $1: 1$ soil to water ratio. The solution produced was filtered and analysed by inductively coupled plasma mass spectrometry with a PerkinElmer model Elan 6000 spectrometer and by optical emission spectrometry with the PerkinElmer Optima 3200 RL spectrometer. Each point value corresponds to an average of three analytical replicates. SPAR was calculated as follows: $\operatorname{SPAR}=(\mathrm{Na}+\mathrm{K}) /(\mathrm{Ca}+\mathrm{Mg})^{1 / 2}$, according to Sarah (2004).

\subsection{Statistical analysis}

Data did not follow the normal distribution and homogeneity of variances, even after logarithmic, square root, and box-cox transformations. Thus, the comparison between the burned and unburned areas was carried out using the non-parametric Mann-Whitney $U(\mathrm{MU})$ test. The Kruskal-Wallis test (K-W) was used to identify significant differences between sampling dates for each response variable. If significant differences were observed at $\mathrm{p}<0.05$, the multiple comparisons rank test was carried out in order to identify differences. Statistical analyses were carried out using Statistica 6.0 (STATSOFT Inc., 2006).

\section{Results}

\section{1. $\mathrm{pH}$, electrical conductivity, and major elements}

Soil pH and EC differed between sampling dates in both the unburned and burned areas. Significant differences were identified in soil $\mathrm{pH}$ between areas on all sampling dates except 9 months after the fire. With the exception of 0 months after the fire, soil $\mathrm{pH}$ was significantly higher in the burned area than in the unburned area on all sampling dates. Significant differences between areas were also identified for soil EC 0 and 2 months after the fire. On both sampling dates the values were significantly higher in the burned area (Table 1 ).

Calcium, $\mathrm{Mg}, \mathrm{Na}$, and $\mathrm{K}$ concentrations were significantly different between sampling dates in the unburned and burned areas. Significant differences for $\mathrm{Ca}$ and $\mathrm{Mg}$ content between areas were only observed on the first sampling date after the fire. The values of both nutrients were significantly higher in the burned area than in the unburned one, while no significant differences were observed between the burned and unburned areas on any of the sampling dates for soil Na content. Soil $\mathrm{K}$ content was always significantly higher in the burned plot than in the unburned one on all sampling dates. We identified decreases in $\mathrm{EC}, \mathrm{Ca}, \mathrm{Mg}$ and $\mathrm{Na}$ from 0 months after the fire to 7 months after in both the burned and unburned areas. Nine months after the fire the values of these nutrients increased significantly in comparison to the previous sampling date (Table 1 ).

\subsection{Minor elements}

Significant differences were observed between sampling dates in the concentrations of $\mathrm{Al}, \mathrm{Mn}, \mathrm{Fe}$, and $\mathrm{Zn}$ in the unburned and burned areas. Aluminium concentration was significantly higher 0 months after the fire in the unburned plot. Significant differences between areas were identified for soil Mn content 0 months, when the content was high in the unburned area, and 9 months after the fire, when Mn concentration was high in the burned plot. The concentration of soil Fe was not significantly different between the burned and unburned areas on any of the sampling dates. Soil $\mathrm{Zn}$ content was significantly higher in the unburned area compared to the burned area 2 and 5 months after the fire (Table 2).

\subsection{Soil ratios}

We observed significant differences in $\mathrm{Ca}: \mathrm{Mg}$ and $\mathrm{Ca}: \mathrm{Al}$ ratios between sampling dates in the burned and unburned areas. No significant differences in SPAR ratio were identified between the burned and unburned areas on any sampling date. The Ca:Mg ratio was significantly higher 0 and 2 months after the fire in the unburned plot. The Ca:Al ratio was significantly higher 0 months after the fire in the burned plot (Table 3).

\section{Discussion}

\section{1. pH, electrical conductivity, and major elements}

The immediate decrease in soil $\mathrm{pH}$ at 0 months in the burned area relative to the unburned area contradicts previous works that investigated the effects of low severity fires on $\mathrm{pH}$, which have documented a non-significant difference (Kutiel and Shaviv, 1992) or significant increase (Blank et al., 2003) in the burned area relative to the unburned one. Normally soil pH increases due to the incorporation of ash into the soil profile (Pereira et al., 2011a). Despite a lack of significant

Table 1

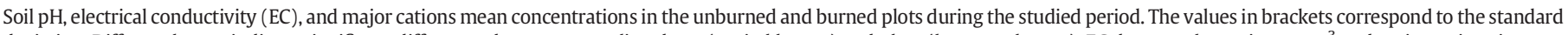

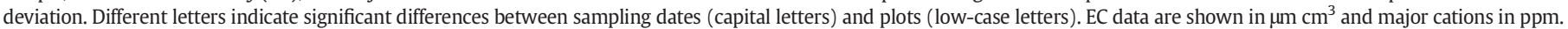
Kruskal-Wallis (K-W) and Mann-Whitney (MU) p-values ( ${ }^{*} \mathrm{p}<0.05,{ }^{* * *} \mathrm{p}<0.001$, and n.s, non-significant at a $\left.\mathrm{p}<0.05\right)$ are shown for each between-date comparison.

\begin{tabular}{|c|c|c|c|c|c|c|c|}
\hline \multirow[t]{2}{*}{ Variable } & \multirow[t]{2}{*}{ Treatment } & \multicolumn{5}{|l|}{ Sampling date } & \multirow{2}{*}{$\begin{array}{l}\mathrm{K}-\mathrm{W} \\
\mathrm{p}\end{array}$} \\
\hline & & 0 months & 2 months & 5 months & 7 months & 9 months & \\
\hline \multirow[t]{3}{*}{$\mathrm{pH}$} & Unburned & $7.63(0.15) \mathrm{Aa}$ & $7.03(0.48) \mathrm{Bb}$ & $6.80(0.48) \mathrm{Bb}$ & $7.01(0.49) \mathrm{Bb}$ & $6.86(0.53) \mathrm{Ba}$ & $* * *$ \\
\hline & Burned & $7.12(0.20) \mathrm{Cb}$ & 7.39(0.13)Aa & $7.28(0.23) \mathrm{BCa}$ & $7.40(0.21) \mathrm{Aa}$ & $7.18(0.12) \mathrm{Ca}$ & $* * *$ \\
\hline & MU p & $* * *$ & * & $* * *$ & $* * *$ & n.s & \\
\hline \multirow[t]{3}{*}{ EC } & Unburned & $219.72(62.52) \mathrm{Ab}$ & $91.92(32.95) \mathrm{Bb}$ & $93.98 \mathrm{~B}(32.52) \mathrm{Ba}$ & 51.24(17.95)Ca & $70.32(22.01) \mathrm{BCa}$ & $* * *$ \\
\hline & Burned & $370.20(97.04) \mathrm{Aa}$ & 164.52(63.51)Ba & 87.63(36.64)Ca & $58.80(14.86) \mathrm{Ca}$ & 79.82(74.22)Ba & $* * *$ \\
\hline & MU p & *** & * & n.s & n.s & n.s & \\
\hline \multirow[t]{3}{*}{$\mathrm{Ca}$} & Unburned & $114.29(28.16) \mathrm{Ab}$ & $57.50(25.45) \mathrm{Ba}$ & 15.73(9.36)Ca & $17.70(13.48) \mathrm{Ca}$ & $55.25(32.25) \mathrm{Ba}$ & $* * *$ \\
\hline & Burned & $135.31(29.80) \mathrm{Aa}$ & $60.40(21.71) \mathrm{Ba}$ & $17.08(5.66) \mathrm{Ca}$ & $21.14(10.19) \mathrm{Ca}$ & 53.61(21.24)Ba & $* * *$ \\
\hline & MU p & $* * *$ & n.s & n.s & n.s & n.s & \\
\hline \multirow[t]{3}{*}{$\mathrm{Mg}$} & Unburned & 14.96(4.67)Ab & $8.49(4.20) \mathrm{Ba}$ & $2.77(1.55) \mathrm{Ca}$ & $2.65(1.66) \mathrm{Ca}$ & 7.33(3.77)Ba & $* * *$ \\
\hline & Burned & 26.53(8.59)Aa & 10.3(4.25)Ba & $3.21(0.76) \mathrm{Ca}$ & $3.32 \mathrm{C}(1.29) \mathrm{Ca}$ & 7.75(2.26)Ba & $* * *$ \\
\hline & MU p & $* * *$ & n.s & n.s & n.s & n.s & \\
\hline \multirow[t]{3}{*}{$\mathrm{Na}$} & Unburned & $97.74(55.91) \mathrm{Ba}$ & $61.06(37.80) \mathrm{Ba}$ & $34.85(14.43) \mathrm{Ca}$ & 52.45(31.59)BCa & 173.62(109.36)Aa & $* * *$ \\
\hline & Burned & 95.39(100.19)Ba & $51.70(41.89) \mathrm{Ca}$ & $45.13(31.33) \mathrm{Ca}$ & $66.30(31.08) \mathrm{Ca}$ & 189.19(100.98)Aa & $* * *$ \\
\hline & MU p & $\mathrm{n} . \mathrm{s}$ & n.s & n.s & n.s & n.s & \\
\hline \multirow[t]{3}{*}{ K } & Unburned & $37.50(14.71) \mathrm{Ab}$ & $21.10(6.57) \mathrm{Bb}$ & $9.47(2.49) \mathrm{Cb}$ & $9.69(3.47) \mathrm{Cb}$ & $2.26(1.49) \mathrm{Db}$ & $* * *$ \\
\hline & Burned & $125.60(30.25) \mathrm{Aa}$ & $45.53(21.43) \mathrm{Ba}$ & $18.69(3.99) \mathrm{Ca}$ & $21.96(5.62) \mathrm{Ca}$ & $5.56(4.34) \mathrm{Da}$ & $* * *$ \\
\hline & MU p & *** & *** & $* * *$ & $* * *$ & & \\
\hline
\end{tabular}


Table 2

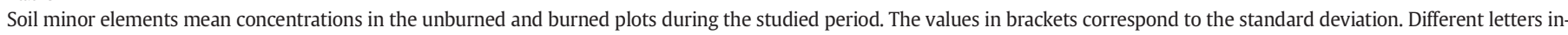

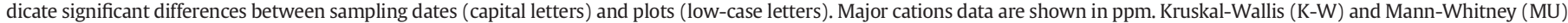
p-values ( ${ }^{*} \mathrm{p}<0.05,{ }^{* * *} \mathrm{p}<0.001$, and $\mathrm{n} . \mathrm{s}$, non-significant at a $\mathrm{p}<0.05$ ) are shown for each between-date comparison.

\begin{tabular}{|c|c|c|c|c|c|c|c|}
\hline \multirow[t]{2}{*}{ Variable } & \multirow[t]{2}{*}{ Treatment } & \multicolumn{5}{|l|}{ Sampling date } & \multirow{2}{*}{$\begin{array}{l}\mathrm{K}-\mathrm{W} \\
\mathrm{p}\end{array}$} \\
\hline & & 0 months & 2 months & 5 months & 7 months & 9 months & \\
\hline \multirow{3}{*}{$\mathrm{Al}$} & Unburned & 1.93(1.15)Ba & 4.81(1.95)Aa & $0.68(0.35) \mathrm{Ca}$ & $1.08(0.45) \mathrm{Ba}$ & 3.12(1.40)Aa & $* * *$ \\
\hline & Burned & $1.40(1.12) \mathrm{Bb}$ & 4.04(2.89)Aa & $0.73(0.28) \mathrm{Ca}$ & $1.15(0.48) \mathrm{Ca}$ & 3.10(1.35)Aa & $* * *$ \\
\hline & MU p & * & n.s & n.s & n.s & n.s & \\
\hline \multirow[t]{3}{*}{ Mn } & Unburned & $0.16(0.12) \mathrm{Ba}$ & $0.26(0.10) \mathrm{Aa}$ & $0.05(0.03) \mathrm{Ca}$ & $0.05(0.04) \mathrm{Ca}$ & $0.22(0.10) \mathrm{Ab}$ & $* * *$ \\
\hline & Burned & $0.10(0.09) \mathrm{Bb}$ & $0.35(0.56) \mathrm{Aa}$ & $0.04(0.02) \mathrm{Ca}$ & $0.04(0.02) \mathrm{Ca}$ & $0.28(0.10) \mathrm{Aa}$ & $* * *$ \\
\hline & MU p & $* * *$ & $\mathrm{n} . \mathrm{s}$ & n.s & n.s & * & \\
\hline \multirow[t]{3}{*}{$\mathrm{Fe}$} & Unburned & 1.98(1.09)Ba & 4.47(1.74)Aa & $0.61(0.42) \mathrm{Ca}$ & $0.74(0.27) \mathrm{Ca}$ & 5.96(6.07)Aa & $* * *$ \\
\hline & Burned & 1.61(1.04)Ca & $3.90(2.53) \mathrm{Ba}$ & $0.73(0.70) \mathrm{Da}$ & 1.12(1.51)Da & 4.48(3.70)Aa & $* * *$ \\
\hline & MU p & n.s & n.s & n.s & n.s & n.s & \\
\hline \multirow[t]{3}{*}{$\mathrm{Zn}$} & Unburned & $0.23(0.19) \mathrm{Aa}$ & $0.25(0.14) \mathrm{Aa}$ & $0.05(0.01) \mathrm{Ba}$ & $0.02(0.01) \mathrm{Ba}$ & $0.20(0.06) \mathrm{Aa}$ & $* * *$ \\
\hline & Burned & $0.22(0.15) \mathrm{Aa}$ & $0.17(0.09) \mathrm{Ab}$ & $0.03(0.01) \mathrm{Cb}$ & $0.02(0.02) \mathrm{Ca}$ & $0.13(0.04) \mathrm{Bb}$ & $* * *$ \\
\hline & MU p & n.s & $*$ & $* * *$ & n.s & $\mathrm{n} . \mathrm{s}$ & \\
\hline
\end{tabular}

differences, Marcos et al. (2009) observed a slight decrease of soil pH in their burned area relative to the unburned one. A potential explanation for the decrease in soil $\mathrm{pH}$ may be soil nitrification at 0 months as observed by Mohamed et al. (2007), as soil nitrification increases soil acidity (Zhou et al., 2014). The fire studied had very little direct impact on the soil surface (Pereira et al., 2014a) and it is very likely that the microbial community was not affected. The most frequent ash colour observed was black (Pereira et al., 2014a), which normally enhances microbial activity due to moderate temperature increases (MataixSolera et al., 2009). For example, nitrification may increase, even for a short period between the fire and the first sampling date (4 days), and normally is high in burned areas (Kutiel and Naveh, 1987). Warmer soils increase nitrate production in burned areas compared to unburned areas (Sharrow and Wright, 1977). Also, the presence of pyrolysed material in soil increases nitrification (Prommer et al., 2014) and promotes the liberation of protons that may have contributed to a $\mathrm{pH}$ decrease (Mohamed et al., 2007). In addition, soil nitrification is higher during the spring and summer than in winter (Casson et al., 2014). The pH decrease could also be attributed to increased levels of Al, which can be released in high quantities by ash produced at low temperatures (Pereira et al., 2011b). However, in this case Al contents were significantly lower in the burned area relative to the unburned one. Thus $\mathrm{Al}$ was not the driver of the soil acidification 0 months after the fire.

In contrast, 2, 5, 7, and 9 months after the fire soil $\mathrm{pH}$ was significantly higher in the burned area and this may be attributed to the incorporation of ash into the soil profile, at least until the second month (Pereira et al., 2015a). This situation was also observed in the study of Marcos et al. (2009), where, in the months following a fire, soil pH was higher in the burned area in comparison to the unburned area, despite the lack of significance. Nevertheless, the authors did not give an explanation for this. In our work we hypothesized that plant consumption in the burned area reduced nitrate in the soil, allowing the soil $\mathrm{pH}$ to increase. The vegetation recovered very fast in the burned area; fortyfive days after the fire the vegetation had recovered completely (Pereira et al., 2016a), and this may be an explanatory mechanism for the hypothesized decrease in soil nitrate which would have led to the corresponding $\mathrm{pH}$ increase 2, 5, 7, and 9 months after the fire.

Soil EC was significantly higher in the burned area 0 and 2 months after the fire. These results agree with previous works which identified an increase in soluble elements in the soil after low-severity fires (Granged et al., 2011), which was attributed to the release of soluble elements from ash incorporated into the soil (Pereira et al., 2011b, 2012, 2014b). Five, 7, and 9 months after the fire no significant difference was observed in soil EC between areas, which we attribute to soil leaching and plant consumption of nutrients in the burned plot, returning electrolytes to pre-fire levels.

Calcium and Mg were significantly higher in the burned area than in the unburned area 0 months after the fire. Similar results were identified in previous studies, which found that these nutrients increase in the soil surface immediately after a fire (Ponder et al., 2009). This was attributed to the same reasons mentioned previously for EC, the dissolution of these elements from ash. In addition to the high availability of these elements, the neutral $\mathrm{pH}$ observed in the soil (7.12) likely favoured the dissolution of these elements, which is optimal in the 7 to $8 \mathrm{pH}$ range (Neary et al., 2005). This fire did not significantly affect $\mathrm{Na}$ content in the soil. Some earlier studies in low severity experimental fires also did not observe changes in Na content respective to the unburned area (Gomez-Rey et al., 2013), while in other works significant differences were identified between burned and unburned areas (Ponder et al., 2009). The lack of impact of this low-severity fire on soil $\mathrm{Na}$ can be explained by the soil $\mathrm{pH}$ values. Soils with $\mathrm{pH}$ values $>8.0-8.5$ are evidence of a high concentration of Na in solution (Guler et al., 2014), which was not achieved in this study. On the other hand, the fire significantly increased $\mathrm{K}$, which was also observed in previous

Table 3

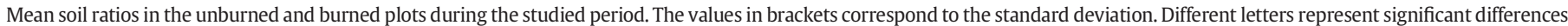

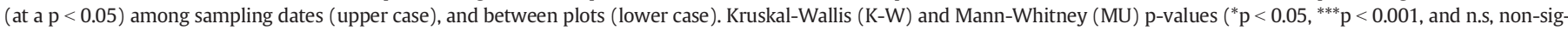
nificant at a $\mathrm{p}<0.05$ ) are shown for each between-date comparison.

\begin{tabular}{|c|c|c|c|c|c|c|c|}
\hline \multirow[t]{2}{*}{ Variable } & \multirow[t]{2}{*}{ Treatment } & \multicolumn{5}{|l|}{ Sampling date } & \multirow{2}{*}{$\begin{array}{l}\mathrm{K}-\mathrm{W} \\
\mathrm{p}\end{array}$} \\
\hline & & 0 months & 2 months & 5 months & 7 months & 9 months & \\
\hline \multirow[t]{3}{*}{ SPAR } & Unburned & 1.37(1.11)Aa & $0.93(0.55) \mathrm{Aa}$ & $0.43(0.28) \mathrm{Ba}$ & $0.37(0.33) \mathrm{Ba}$ & $0.53(0.61) \mathrm{Ba}$ & $* * *$ \\
\hline & Burned & $0.86(0.38) \mathrm{Aa}$ & $0.85(0.48) \mathrm{Aa}$ & $0.37(0.15) \mathrm{Ba}$ & $0.29(0.13) \mathrm{Ba}$ & $0.37(0.19) \mathrm{Ba}$ & $* * *$ \\
\hline & MU p & n.s & n.s & n.s & n.s & n.s & \\
\hline \multirow[t]{3}{*}{ Ca:Mg } & Unburned & 7.91:1(1.34)Aa & $6.92: 1(0.79) \mathrm{Ba}$ & $5.54: 1(1.14) \mathrm{C}$ & $6.20: 1(1.48) \mathrm{B}$ & 7.26:1(1.60)AB & $* * *$ \\
\hline & Burned & $5.27: 1(0.66) \mathrm{Cb}$ & $6.01: 1(0.51) \mathrm{Bb}$ & $5.24: 1(0.98) \mathrm{C}$ & $6.32: 1(1.35) \mathrm{AB}$ & $6.90: 1(1.54) \mathrm{A}$ & $* * *$ \\
\hline & MU p & $* * *$ & $* * *$ & n.s & n.s & n.s & \\
\hline \multirow[t]{3}{*}{$\mathrm{Ca}: \mathrm{Al}$} & Unburned & $84.71(60.80) \mathrm{Ab}$ & 17.57(18.77)Ca & 30.12(27.34)Ba & 26.94(31.48)Ba & 23.38(19.58)ВСа & $* * *$ \\
\hline & Burned & 142.51(90.03)Aа & $22.83(23.21) \mathrm{Ba}$ & 28.11(17.35)Ba & $25.40(23.24) \mathrm{Ba}$ & 21.31(15.62)Ba & $* * *$ \\
\hline & MU p & $* * *$ & n.s & n.s & n.s & n.s & \\
\hline
\end{tabular}


studies carried out in low-severity burnings (Knoepp et al., 2004). The concentration of this element was always significantly higher in the burned area relative to the unburned area. Soil pH $>7.0$ favours the solubility of K (Neary et al., 2005).

No significant differences occurred in Ca and Mg between areas at 2, 5,7 , and 9 months after the fire, and this was attributed to the same reasons mentioned previously for EC. Calcium and Mg levels also decreased each month from 0 through 7 months. Previous works have observed a reduction of $\mathrm{Ca}$ and $\mathrm{Mg}$ elements in burned areas (Gomez-Rey et al., 2013; Martin et al., 2012). However, the content of soil K was significantly higher in the burned area for the entire studied period. This can be attributed to the disturbance induced by fire, which affects plant nutrient uptake (Shenoy et al., 2013) and it is very likely that the uptake of some elements were favoured relative to others (Barot et al., 2014). On the other hand, antagonism among nutrients has implications on their availability to plants (Brevik, 2009; Pii et al., 2015). According to Wakeel (2013), Na competes with K for plant uptake due to their similar physicochemical characteristics. Sodium causes plant membrane depolarization making it difficult for $\mathrm{K}$ to be taken up by roots. This may limit $\mathrm{K}$ plant consumption and help create the significantly higher quantities of this nutrient in the burned area relative to the unburned area on all sampling dates. Overall there was a decrease in EC, $\mathrm{Ca}, \mathrm{Mg}$ and $\mathrm{Na}$ from 0 to 7 months after the fire. Nine months after the fire (sampling date in January, winter time) there was a slight increase in these variables. This can be attributed to two factors: a) the continuation of microbial activity during winter time, as previous works observed that there is a continuation of microbial activity, even during temperatures $<0{ }^{\circ} \mathrm{C}$, and an increase in the nutrients available to plants during the winter period in northern latitudes (Edwards et al., 2006); and $b$ ) the decrease in plant nutrient consumption during winter time due to low temperatures, root damage and reduced photosynthetic activity from frost conditions (Larsen et al., 2012). These factors may have contributed to the increase in nutrients observed 9 months after the fire in both the unburned and burned areas.

\subsection{Minor elements}

This grassland fire significantly reduced the amount of water extractable $\mathrm{Al}$ and $\mathrm{Mn}$ and did not impact water extractable Fe and $\mathrm{Zn}$. Fire normally decreases the availability of minor elements due to the increase of soil and ash $\mathrm{pH}$, which reduces the solubility of these nutrients (Ballard, 2000; Pereira et al., 2012, 2014b). The combusted organic matter incorporated into the soil has significant impacts on soil amount and type of available nutrients in the period immediately after a fire (Bodí et al., 2014). The pH levels observed in the unburned and burned soils 0 months after the fire were not favourable for the solubility of $\mathrm{Al}, \mathrm{Mn}$, Fe and $\mathrm{Zn}$. Aluminium is very mobile at $\mathrm{pH}<5$ and has a low solubility in the range of pH 5 to 8 (Lee et al., 2002). This may explain the reduced solubility of this element 0 months after the fire, but does not clarify the significant decrease in the burned area. Previous works observed that the high presence of $\mathrm{Ca}, \mathrm{Mg}$, and $\mathrm{K}$ in solution can inhibit the solubility of $\mathrm{Al}$, and vice-versa, representing an antagonism between these elements on the soil exchange sites (Scholl et al., 2004). This may be the cause of the decrease of soil $\mathrm{Al}$ in the burned area 0 months after the fire, since $\mathrm{Ca}, \mathrm{Mg}$, and $\mathrm{K}$ increased significantly. Two months after the fire there was an increase of soil $\mathrm{Al}$ content in the burned and unburned areas and this may be attributed to plant consumption or leaching of $\mathrm{Ca}$, $\mathrm{Mg}$, and $\mathrm{K}$, which decreased significantly in both areas after 2 months. This situation may have contributed to the increase of soluble Al.

Soil Mn has reduced solubility at the $\mathrm{pH}$ levels observed in the burned and unburned areas. The pH range of Mn solubility is similar to $\mathrm{Al}$ (Lee et al., 2002). At pH levels higher than 7-8 a strong decrease in Mn solubility is observed (Zeng et al., 2011). This may explain the low levels of Mn in solution. As in soil Al, the concentration of this nutrient 0 months after the fire was significantly higher in the unburned than the burned area despite $\mathrm{pH}$ levels being lower in the latter. The presence of Ca and Mg in solution decreases the bioavailability of Mn (Fernando and Lynch, 2015). The antagonism between $\mathrm{Mn}$ and major cations may be the cause for the significant reduction of their contents in the burned area, relative to the unburned area, since 0 months after the fire, the amount of Ca and Mg increased significantly, similar to the discussion in the case of Al. Two months after the fire the levels of Mn increased in both areas, which was opposite to the significant decrease observed for Ca and Mg.

This fire did not affect soil Fe concentration in the soil 0 months after the fire. This was attributed to the high $\mathrm{pH}$ not being favourable to $\mathrm{Fe}$ solubility. According to Lee et al. (2002), the solubility of Fe is reduced at $\mathrm{pH}>4$. As observed in this work, $\mathrm{pH}$ values in both areas were above 7 , inhibiting the presence of this metal in solution. An increase of Fe in solution was also observed two months after the fire and this may be attributed to antagonistic effects. As with $\mathrm{Al}$ and $\mathrm{Mn}$, the presence of other ions in solution affects the availability of Fe. High quantities of Ca and $\mathrm{K}$ decrease the amount of Fe in solution (Varennes, 2003).

Finally, the fire did not have significant impacts on soil $\mathrm{Zn}$. The $\mathrm{pH}$ values observed in the burned and unburned areas did not favour the solubility of this nutrient. Soil $\mathrm{Zn}$ is strongly reduced at $\mathrm{pH}>5-6$ (Speir et al., 2003). Thus, we assume that because of the pH levels observed in the studied soils, the presence of $\mathrm{Zn}$ in solution was decreased. Contrary to the other studied metals, we did not observe a significant increase of $\mathrm{Zn}$ values in solution two months after the fire, the values were very similar. Zinc availability is reduced by the presence of major cations (Baker, 1978), Al, and Fe (Gibert et al., 2005) in solution. This fact, coupled with consumption by vegetation (Pereira et al., 2016a), may explain the lack of increase of this element 2 months after the fire. As in the case of the major elements, there was a decrease in the content of all minor elements (with the exception of $\mathrm{Al}$ ) in both areas, which is attributed to the reasons mentioned above for the major elements, namely vegetation recuperation and soil leaching. An increase in the content of all minor elements 9 months after the fire was also observed, which may be attributed to the same causes mentioned in the previous section for the major elements.

\subsection{Soil ratios}

The SPAR ratio did not show significant differences between the burned and unburned areas. We observed a non-significant decrease in SPAR 0 months after the fire that may be attributed to the increase of soil $\mathrm{Ca}$ and $\mathrm{Mg}$ and the lack of the fire's impact on Na. Despite the significant increase of $\mathrm{K}$, it was not enough to counterbalance the effects of the bivalent cations. On the other sampling dates, the values of SPAR in both areas were very similar. Previous works observed that SPAR increased in soils after a rainfall (Francos et al., 2016) and in ash slurries (Pereira et al., 2014b) in samples collected in areas affected by high severity fires. Similar to SPAR, SAR levels are higher in soils burned in the laboratory as compared to unburned samples (Inbar et al., 2014), and increase with the temperature of combustion (Badia and Marti, 2003). This situation was also observed in field fires by Blank et al. (2003).

The Ca:Mg ratio was significantly lower in the burned area 0 and 2 months after the fire. This showed that the impact of fire on soil $\mathrm{Mg}$ was higher than on Ca. Despite this significant decrease in the burned area on the first two sampling dates after the fire, the mean values observed (5.27:1 and 6.01:1) were not considered high enough to induce soil dispersion. Previous works observed that Ca:Mg ratios lower than 1:1 can reduce soil infiltration and hydraulic conductivity and degrade soil structural stability (Bame et al., 2013). Thus, in this case, the potential effects on clay dispersion and soil structure may be reduced. To our knowledge, no previous work has been carried out to investigate the impacts of fire on the Ca:Mg ratio. Further studies are needed to understand the impact of fire on this ratio given differing soil conditions and fire severities.

Fire significantly increased the Ca:Al ratio 0 months after the fire. This suggests that fire reduced the impact of Al. This was attributed to 
the large amounts of Ca released and the significant reduction observed in water available $\mathrm{Al}$ content. We did not find values of $\mathrm{Ca}$ :Al below the aluminium stress threshold $(<1)$ (Levia et al., 2015) on any of the sampling dates studied, thus there was no risk of aluminium stress to plants. Overall, decreasing SPAR with time was observed in both areas, while no clear trend was observed for the other ratios. Nevertheless, a strong reduction of $\mathrm{Ca}: \mathrm{Al} 2$ months after the fire was identified, which may be attributed to the high plant consumption of $\mathrm{Ca}$ and the slight increase of Al.

\subsection{Overall discussion and implications for land management}

This low-severity fire did not have direct or indirect negative impacts on soil properties. Normally, spring grassland fires do not have a major impact on soil properties and seed banks (Ruprecht et al., 2013). The ash produced by the fire increased the amount of available nutrients and acted as a mulch during the 2 months post-fire, which is fundamental for plant reestablishment (Pereira et al., 2015a, 2015b). This is very important since soils are highly vulnerable to erosion and degradation in the immediate post-fire period. This vulnerability decreases as the vegetation recovers (Cerda, 1998). One and a half months after the fire the vegetation recovered completely as a consequence of the nutrient increases, spring season, and rainfall in the post-fire period (Pereira et al., 2016a). The impacts of fire on soil properties were mainly restricted to the immediate post-fire period, and this was due to the high rainfall in the immediate period after the fire (Pereira et al., 2016a).

Spring grassland fires in these ecosystems are beneficial. In Lithuania, the use of fire for management proposes is illegal and considered dangerous by Lithuanian authorities. In addition, the attitude regarding fire use is normally negative as a consequence of the lack of knowledge concerning fire effects on ecosystems (Pereira et al., 2016b). In this context, the application of controlled fires by farmers after the winter to remove dried grasses and improve soil properties for crop production is limited by the political context and stakeholders' understanding about fire effects on the ecosystem. In the work of Pereira et al. (2016b) farmers highlighted the importance of fire to increase nutrients in the soil and felt fire was beneficial to agricultural production. Previous works have highlighted the importance of low-severity prescribed fires for forest landscape management and to reduce the risk of large wildfires in other European grasslands (Valko et al., 2016), the Mediterranean environment (Pinol et al., 2005), and in temperate (Hancock et al., 2009) and boreal ecosystems (Vanha-Majamaa et al., 2007). Removing political restrictions would be important to return the ecological role of fire in boreal grasslands (Pykala, 2000).

\section{Conclusions}

The studied fire did not have negative impacts on soil properties and contributed to the increased availability of key soil nutrients, such as $\mathrm{Ca}$, $\mathrm{Mg}$, and $\mathrm{K}$, in the period immediately after the fire despite the slight decrease in $\mathrm{pH}$ values. This increase was mainly limited to the first months after the fire with the exception of $\mathrm{K}$. The presence of minor nutrients in solution was reduced because of $\mathrm{pH}$ levels, but also as a consequence of antagonistic effects which limited their availability. Soil SPAR was not affected by this fire and Ca:Mg decreased slightly, showing that the impact of the post-fire soil solution on clay dispersion and soil aggregate stability may not be a concern. Ca:Al increased immediately after the fire, reducing soil acidity and the effects of Al on plant growth. Until 7 months after the fire a decrease in soil EC, $\mathrm{Ca}, \mathrm{Mg}$, and $\mathrm{Na}$ was observed. Nine months after the fire an increase of these elements was identified, which may be attributed to the continuation of microbiological activity and reduced plant nutrient consumption during winter time. Overall, the impacts of this fire were limited to the first few months. Future research is needed to understand the long-term and repeated effects of fire in boreal grasslands.

\section{Acknowledgments}

The authors would like to acknowledge the Lithuanian Research Council for financing the project LITFIRE, Fire effects on Lithuanian soils and ecosystems (MIP-48/2011), to Comissionat per a Universitats i Recerca del DIUE de la Generalitat de Catalunya. Soil quality, erosion control and plant cover recovery under different post-fire management scenarios (POSTFIRE) was funded by the Spanish Ministry of Economy and Competitiveness (CGL2013-47862-C2-1-R). We acknowledge the important help of two anonymous reviewers that improved the quality of this work.

\section{References}

Badia, D., Marti, C., 2003. Plant ash and heat intensity effects on chemical and physical properties of two contrasting soils. Arid Land Res. Manag. 17, 23-41.

Badia, D., Marti, C., Aguirre, A., Aznar, J.M., Gonzalez-Perez, J.A., De la Rosa, J.M., Leon, J., Ibarra, P., Echeverria, T., 2014. Wildfire effects on nutrients and organic carbon of Rendzic Phaeozem in NE Spain: changes at cm-scale topsoil. Catena 113, 267-275.

Baker, A.J.M., 1978. The uptake of zinc and calcium from solution culture by zinc-tolerant and non-tolerant Silene maritima With. in relation to calcium supply. New Phytol. 81, 321-330.

Ballard, T.M., 2000. Impacts of forest management on northern soils. For. Ecol. Manag. 1-2, 37-432.

Bame, I.B., Hughes, J.C., Titshall, L.W., Buckley, C.A., 2013. Leachate characteristics as influenced by application of anaerobic baffled reactor effluent to three soils: a soil column study. Chemosphere 93, 2171-2179.

Barot, S., Bornnhofen, S., Loeuille, N., Perveen, N., Shahzad, T., Fontaine, S., 2014. Nutrient enrichment and local competition influence the evolution of plant mineralization strategy: a modelling approach. J. Ecol. 102, 357-366.

Blank, R.R., Chambers, J.C., Zamudio, D., 2003. Restoring riparian corridors with fire: effects on soil and vegetation. J. Range Manag. 56, 388-396.

Bodí, M., Martin, D.A., Santin, C., Balfour, V., Doerr, S.H., Pereira, P., Cerda, A., MataixSolera, J., 2014. Wildland fire ash: production, composition and eco-hydrogeomorphic effects. Earth-Sci. Rev. 130, 103-127.

Brevik, E.C., 2009. Soil, food security, and human health. In: Verheye, W. (Ed.), Soils, Plant Growth and Crop Production. Encyclopedia of Life Support Systems (EOLSS), Developed Under the Auspices of the UNESCO. EOLSS Publishers, Oxford, UK http:// www.eolss.net (Accessed 15 September 2016).

Brook, A., Wittenberg, L., 2016. Ash-soil interface: mineral composition and physical structure. Sci. Total Environ. http://dx.doi.org/10.1016/j.scitotenv.2016.02.123 .

Campos, I., Abrantes, N., Keiser, J.J., Vale, C., Pereira, P., 2016. Major and trace elements in soils and ashes of eucalypt and pine forest plantations in Portugal following a wildfire. Sci. Total Environ. http://dx.doi.org/10.1016/j.scitotenv.2016.01.190 .

Casson, N.J., Eimers, M.C., Watmough, S.A., 2014. Controls on soil nitrification and stream nitrate export at two forested catchments. Biogeochemistry 121, 355-368.

Cerda, A., 1998. Changes in overland flow and infiltration after a rangeland fire in a Mediterranean scrubland. Hydrol. Process. 12, 1031-1042.

Certini, G., 2005. Effects of fire on properties of forest soils: a review. Oecologia 143, 1-10. Certini, G., 2014. Fire as a soil-forming factor. Ambio 43, 191-195.

Cronan, C., Grigal, D.F., 1995. Use of calcium/aluminium ratios as indicators in forests ecosystems. J. Environ. Qual. 24, 209-226.

Drzewiecka, K., Mleczeck, M., Gasecka, M., Magdziak, M., Golinski, P., Chadzinikolau, T., 2014. Cooper phytoextraction with Salix purpurea $\mathrm{x}$ viminalis under various $\mathrm{Ca} / \mathrm{Mg}$ ratios. Part 2. Effect on organic acid, phenolics and salicylic acid contents. Acta Physiol. Plant. 36, 903-913.

Edwards, K.A., McCulloch, J., Kershaw, G.P., Jefferies, R.L., 2006. Soil microbial and nutrient dynamics in a wet Artic sedge meadow in late winter and early spring. Soil Biol. Biochem. 38, 2843-2851.

Favaretto, N., Norton, L.D., Johnston, C.T., Bigham, J., Sperrin, M., 2012. Nitrogen and phosphorous leaching as affected by gypsum amendment and exchangeable calcium and magnesium. Soil Sci. Soc. Am. J. 76, 575-585.

Fernando, D.R., Lynch, J.P., 2015. Manganese phytoxicity: new light on an old problem Ann. Bot. 116, 313-319.

Francos, M., Pereira, P., Alcaniz, M., Mataix-Solera, J., Úbeda, X., 2016. Intense rainfall impact on soil properties in fire affected areas. Sci. Total Environ. http://dx.doi.org/10 1016/j.scitotenv.2016.01.145

Gibert, O., Pablo, J., Cortina, J., Ayora, C., 2005. Municipal and compost-based mixture acid mine drainage bioremediation: metal retention mechanisms. Appl. Geochem. 20 1648-1657.

Gimeno-Garcia, E., Andreu, V., Rubio, J.L., 2000. Changes in organic matter, nitrogen, phosphorous and cations in soil as a result of fire and water erosion in a Mediterranean landscape. Eur. J. Soil Sci. 51, 201-210.

Giovannini, G., Lucchesi, S., Giachetti, M., 1988. Effect of soil heating on some chemical parameters related to soil aggregation and erodibility. Soil Sci. 146, 255-262.

Gomez-Rey, M.X., Couto-Vasquez, A., Garcia-Marco, S., Gonzalez-Prieto, S.J., 2013. Impact of fire and post fire management techniques on soil chemical properties. Geoderma 195-196, 155-164

Granged, A.J.P., Zavala, L.M., Jordan, A., Barcenas-Moreno, G., 2011. Post-fire evolution of soil properties and vegetation cover in a Mediterranean heathland after experimental burning: a 3-years study. Geoderma 164, 85-94. 
Granstrom, A., 2001. Fire management for biodiversity in European boreal forest. Scand. J. For. Res. 3, 62-69.

Granstrom, A., Niklasson, M., 2008. Potentials and limitations for human control over historic fire regimes in boreal forest. Philos. Trans. R. Soc. B 363, 2353-2358.

Guler, M., Arslan, H., Cemejk, M., Ersahin, S., 2014. Long-term changes in spatial variation of soil electrical conductivity and exchangeable sodium percentage in irrigated mesic ustifluvents. Agric. Water Manag. 135, 1-8.

Hancock, M.H., Summers, R.W., Amphlett, A., Will, J., 2009. Testing prescribed fire as a tool to promote Scots pine Pinus sylvestris regeneration. Eur. J. For. Res. 128, 319-333.

Inbar, A., Lado, M., Sternberg, M., Tenau, H., Ben-Hur, M., 2014. Forest fire effects on soil chemical and physicochemical properties. Infiltration, runoff, and erosion in a semiarid Mediterranean region. Geoderma 221-222, 131-138.

Knoepp, J.D., Vose, J., Swank, W.T., 2004. Long-term soil responses to site preparation burning in the southern Appalachians. For. Sci. 50, 540-550.

Kopsell, D.E., Kopsell, D.A., Sams, C.E., Barickman, T.C., 2013. Ratio of calcium to magnesium influences biomass, elemental accumulations, and pigment concentrations in Kale. J. Plant Nutr. 36, 2157-2165.

Kutiel, P., Naveh, Z., 1987. The effect of fire on nutrients in a pine forest soil. Plant Soil 104, 269-274.

Kutiel, P., Shaviv, A., 1992. Effects of soil type, plant composition and leaching on soil nutrients follow a simulated forest fire. Forest Ecol. Manag. 53, 329-343.

Larsen, K.S., Michelsen, A., Jonasson, S., Beier, C., Grogan, P., 2012. Nitrogen uptake during Fall, Winter and Spring differs among plant functional groups in a subartic health ecosystem. Ecosystems 15, 927-939.

Lee, G., Bigham, J.M., Faure, G., 2002. Removal of trace metals by coprecipitation with Fe, $\mathrm{Al}$ and $\mathrm{Mn}$ from natural waters contaminated with acid mine drainage in the Ducktown Mining District, Tennessee. Appl. Geochem. 17, 569-581.

Levia, D.F., Shiklomanov, A.N., van Stan Jr., D.F., Scheick, C.E., Inamdar, S.P., Mitchell, M.J. McHale, P.J., 2015. Calcium and aluminium cycling in a temperate broadleaved deciduous forest of the eastern USA: relative impacts of tree species, canopy state, and flux type. Environ. Monit. Assess. 187, 458.

Levy, G.J., Torrento, J.R., 1995. Clay dispersion and macroaggregate stability as affected by exchangeable potassium and sodium. Soil Sci. 5, 352-358.

Lombini, A., Llugani, M., Poschenrieder, C., Dinelli, E., Barcelo, J., 2003. Influence of Ca/Mg ratio on $\mathrm{Cu}$ resistance in three Silene armeria ecotypes adapted to calcareous soil or to different, Ni or Cu-enriched, serpentine sites. J. Plant Physiol. 12, 1451-1456.

Manimel Wadu, M.C.W., Michaelis, V.K., Kroeker, S., Akinremi, O., 2013. Exchangeable Calcium/Magnesium ratio affects phosphorous behaviour in calcareous soils. Soil Sci. Soc. Am. J. 77, 2004-2013.

Marcos, E., Tarrega, R., Luis, E., 2007. Changes in Humic Cambisol heated $\left(100-500{ }^{\circ} \mathrm{C}\right)$ under laboratory conditions: the significance of heating time. Geoderma 138, 237-243.

Marcos, E., Villalon, C., Calvo, L., Luis-Calabuig, E., 2009. Short-term effects of experimental burning on soil nutrients in the Cantabrian heathlands. Ecol. Eng. 35, 820-828.

Martin, A., Diaz-Ravina, M., Carballas, T., 2012. Short-and medium term evolution of soil properties in Atlantic forest ecosystems affected by wildfires. Land Degrad. Dev. 23, 427-439.

Martínez-Murillo, J.F., Hueso-González, P., Ruiz-Sinoga, J.D., Lavee, H., 2016. Short-term experimental fire effects in soil and water losses in southern of Spain. Land Degrad. Dev. 27, 1513-1522.

Mataix-Solera, J., Guerrero, C., Garcia-Orenes, F., Barcenas, G.M., Pilar Torres, M., 2009. Fores fire effects on soil microbiology. In: Cerda, A., Robichaud, P. (Eds.), Fire Effect on Soils and Restoration Strategies. Science Publishers, Enfield (NH), Jersey, pp. 133-175.

Mohamed, A., Hardtle, W., Jirjahn, B., Niemeyer, T., von Oheimb, G., 2007. Effects of prescribed burning on plant available nutrients in dry heathland ecosystems. Plant Ecol. 189, 279-289.

Murphy, J.D., Johnson, D.W., Miller, W.W., Walker, R.F., Carrol, E.F., Blank, R.R., 2006. Wildfire effects on soil nutrients and leaching in a Tahoe basin watershed. J. Environ. Qual. $35,479-489$.

Narhi, P., Gustavsson, N., Sutinen, M.L., Mikkola, K., Sutinen, R., 2013. Long-term effect of site preparation on soil quality in Tunsta, Finnish Lapland. Geoderma 192, 1-6.

Neary, D.G., Ryan, K., DeBano, L.F., 2005. Wildland fire in ecosystems: effects of fire on soil and water. Gen. Tech. Rep. RMRS-GTR-42-vol. 4. U.S. Department of Agriculture, Forest Service, Rocky Mountain Research Station, Ogden, UT pp. 250.

Pereira, P., Úbeda, X., Martin, D., Mataix-Solera, J., Guerrero, C., 2011a. Effects of a low prescribed fire in ash water soluble elements in a Cork Oak (Quercus suber) forest located in Northeast of Iberian Peninsula. Environ. Res. 111, 237-247.

Pereira, P., Úbeda, X., Martin, D., 2011b. Heavy metals released from leaf litter exposed to different fire temperatures. A laboratory experiment. Sustainable Development Strategy and Practice $1,137-154$

Pereira, P., Úbeda, X., Martin, D., 2012. Fire severity effects on ash chemical composition and water-extractable elements. Geoderma 191, 105-114.

Pereira, P., Pranskevicius, M., Cepanko, V., Vaitkute, D., Pundyte, N., Úbeda, X., MataixSolera, J., Cerda, A., Martin, D., 2013a. Short-term vegetation recovery after a spring grassland fire in Lithuania. Effect of time and slope position. Flamma 4, 13-17.

Pereira, P., Cerda, A., Jordan, A., Bolutiene, V., Pranskevicius, M., Úbeda, X., Mataix-Solera, J., 2013b. Spatio-temporal vegetation recuperation after a grassland fire in Lithuania. Prog. Environ. Sci. 19, 856-864

Pereira, P., Cerda, A., Úbeda, X., Mataix-Solera, J., Jordan, A., Burguet, M., 2013c. Spatia models for monitoring the spatio-temporal evolution of ashes after fire - a case study of a burnt grassland in Lithuania. Solid Earth 4, 153-165.

Pereira, P., Úbeda, X., Mataix-Solera, J., Oliva, M., Novara, A., 2014a. Short-term spatiotemporal spring grassland fire effects on soil colour, organic matter and water repellency in Lithuania. Solid Earth 5, 209-225.

Pereira, P., Úbeda, X., Martin, D., Mataix-Solera, J., Cerda, A., Burget, M., 2014b. Wildfire effects on extractable elements in ash from Pinus pinaster forest in Portugal. Hydrol. Process. 28, 2681-3690.
Pereira, P., Jordan, A., Cerda, A., Martin, D., 2015a. Editorial: the role of ash fire in fire affected ecosystems. Catena 135, 337-339.

Pereira, P., Cerda, A., Úbeda, X., Mataix-Solera, J., Arcenegui, V., Zavala, L., 2015b. Modelling the impacts of wildfire on ash thickness in a short term period. Land Degrad. Dev. 26, 180-192.

Pereira, P., Cerda, A., Jordan, A., Zavala, L., Mataix-Solera, J., Arcenegui, V., Misiune, I., Kesstra, S., Novara, A., 2016a. Vegetation recovery after a grassland in Lithuania. Effects of fire severity, slope position and aspect. Land Degrad. Dev. 27, 1523-1534.

Pereira, P., Mierauskas, P., Novara, A., 2016b. Stakeholders perception about fire impact in protected areas. Land Degrad. Dev. 27, 871-883.

Pii, Y., Cesco, S., Mimmo, T., 2015. Shoot ionome to predict the synergism and antagonism between nutrients as affected by substrate and physiological traits. Plant Physiol. Biochem. 94, 48-56.

Pils, J.R.V., Laird, D.A., Evangelou, V.P., 2007. Role of cation demixing and quasicrystal formation and breakup on stability of smectitic colloids. Appl. Clay Sci. 35, 201-211.

Pinol, J., Beven, K., Viegas, D.X., 2005. Modelling the effect of fire-exclusion and prescribed fire on wildfire size in Mediterranean ecosystems. Ecol. Model. 183, 397-409.

Ponder Jr., F., Tadros, M., Lowenstein, E.F., 2009. Microbial properties and litter and soil nutrients after two prescribed fires in developing savannas in an upland Missouri Ozark Forest. For. Ecol. Manag. 257, 755-763.

Prommer, J., Wanek, W., Hofhans, F., Trojan, D., Offre, P., Urich, T., Schleper, C., Sassmann, S., Kitzler, B., Soja, G., Hood-Nowotny, C., 2014. Biochar decelerates soil organic nitrogen cycling but stimulates soil nitrification in a temperate arable field trial. PLoS One 9, e86388.

Pykala, J., 2000. Mitigating human effects on European biodiversity trough traditional animal husbandry. Conserv. Biol. 14, 705-712.

Raison, R.J., McGarity, J.W., 1980. Some effects of plant ash on the chemical properties of soils and aqueous suspensions. Plant Soil 55, 339-352.

Ruprecht, E., Fenesi, A., Fodor, I., Kuhn, T., 2013. Prescribed burning as an alternative management in grasslands of temperate Europe: the impact on seeds. Basic Appl. Ecol. 14, 642-650.

Sarah, P., 2004. Soil sodium and potassium adsorption ratio along a Mediterranean-arid transect. J. Arid Environ. 59, 731-741.

Scholl, L.V., Keltjens, W.G., Hoffland, H., Breemen, N.V., 2004. Aluminium concentration versus the base cation to aluminium ratio as predictors for aluminium toxicity in Pinus sylvestris and Picea abies seedlings. Forest Ecol. Manag. 195, 301-309.

Shakesby, R.A., Bento, C.P.M., Ferreira, C.S.S., Ferreira, A.J.D., Stoof, C.R., Urbanek, E., Walsh, R.P.D., 2015. Impacts of prescribed fire on soil quality: an assessment based on an experimentally-burned catchment in central Portugal. Catena 128, 278-293.

Sharrow, S.H., Wright, H.A., 1977. Effects of fire, ash, and litter on soil nitrate, temperature, moisture and tobograss production in the Rolling Plains. J. Range Manag. 30, 266-270.

Shenoy, A., Kielland, K., Johnstone, J.F., 2013. Effects of fire severity on plant nutrient uptake reinforce alternate pathways of succession in boreal forests. Plant Ecol. 214, 587-596.

Speir, T.W., Van Shaik, A.P., Percival, H.J., Close, M.E., Pang, L., 2003. Heavy metals in soil, plants and groundwater following high-rate sewage sludge application to land. Water Air Soil Pollut. 150, 319-358.

StatSoft Inc., 2006. STATISTICA, Version 6.0., Tulsa, OK

Tomaz, E.L., Antoneli, V., Doerr, S., 2014. Effects of fire on the physicochemical properties of soil in a slash-and-burn agriculture. Catena 122, 209-215.

Úbeda, X., Lorca, M., Outeiro, L.R., Bernia, S., Castellnou, M., 2005. Effects of prescribed fire on soil quality in Mediterranean grassland (Prades mountains, north-east Spain). Int. J. Wildland Fire 14, 379-384.

Unzue-Belmonte, D., Struyf, E., Clymans, W., Tischer, A., Potthast, K., Bremer, M., Meire, P., Schaller, J., 2016. Fire enhances solubility of biogenic silica. Sci. Total Environ. http:// dx.doi.org/10.1016/j.scitotenv.2015.12.085

Valko, O., Deak, B., Magura, T., Torok, P., Kelemen, A., Toth, K., Horvath, R., Nagy, D.D., Debnar, Z., Zsigrai, G., Kapocsi, I., Tothmeresz, B., 2016. Supporting biodiversity by prescribed burning in grasslands - a multi-taxa approach. Sci. Total Environ. http:// dx.doi.org/10.1016/j.scitotenv.2016.01.184

Vanha-Majamaa, I., Lija, S., Ryoma, R., Kotiaho, J.S., Laaka-Lindberg, S., Lindberg, H., Puttonen, P., Tamminen, T., Toivanen, T., Kuuluvainen, T., 2007. Rehabilitating boreal forest structure and species composition in Finland through logging, dead wood creation and fire: the EVO experiment. For. Ecol. Manag. 250, 77-88.

Varennes, A., 2003. Produtividade dos solos e Ambiente. Escolar Editora, Lisboa 490p.

Végvári, Z., Valkó, O., Deák, B., Török, P., Konyhás, S., Tóthmérész, B., 2016. Effects of land use and wildfires on the habitat selection of great bustard (Otis tarda l.). Implications for species conservation. Land Degrad. Dev. 27, 910-918.

Wakeel, A., 2013. Potassium-sodium interactions in soil and plant under saline-sodic conditions. J. Plant Nutr. Soil Sci. 176, 344-354.

Wang, C., Wang, G., Wang, Y., Rafique, R., Ma, L., Hu, L., Luo, Y., 2016. Fire alters vegetation and soil microbial community in alpine meadow. Land Degrad. Dev. http://dx.doi.org/ 10.1002/ldr.2367

WRB, 2014. World reference base for soil resources 2006. World Soil Resources Reports, No 103, second ed. Food and Agriculture Organization of the United Nations, Rome .

Yilmaz, K., Celik, I., Kapur, S., Ryan, J., 2005. Clay minerals, Ca/Mg ratio and Fe-Al-oxides in relation to structural stability, hydraulic conductivity and soil erosion in Southeasthern Turkey. Turk. J. Agric. For. 29, 29-37.

Zeng, F., Ali, S., Zhang, H., Ouyang, Y., Qiu, B., Wu, F., Zhang, G., 2011. The influence of pH and organic matter content in paddy soil on heavy metal availability and their uptake by plants. Environ. Pollut. 159, 84-91.

Zhou, J., Xia, F., Liu, X., He, Y., Xu, J., Brookes, P.C., 2014. Effects of nitrogen fertilizer on the acidification of two typical acid soils in south China. J. Soils Sediments 14, 415-422. 